\title{
From natural forest to coffee agroforest: implications for communities of large mammals in the Ethiopian highlands
}

\author{
Jan E. J. Mertens, Willem-Jan Emsens, Merlijn Jocqué \\ Lore Geeraert and Matthias De Beenhoumer
}

\begin{abstract}
In tropical regions the extent of agricultural land is increasing rapidly at the expense of natural forest, with associated losses of biodiversity and ecosystem services. Agroforestry has long been proposed as a more sustainable agricultural system, conserving biodiversity while providing significant local livelihoods. In this context, camera traps were deployed to compare communities of large mammals between natural forest (22,272 hours across 24 deployments) and extensively managed coffee forest (19,059 hours, 23 deployments) for the first time in the south-west Ethiopian highlands. Mammal communities in the two forest types were similar in species richness and Shannon diversity but differed in community composition. Significant indicator species of coffee forest were the crested porcupine Hystrix cristata and the Ethiopian hare Lepus fagani, whereas leopards Panthera pardus and civets Civettictis civetta had a preference for natural forest. The number of detections of mammals was higher in coffee forest, where activity patterns were predominantly crepuscular and nocturnal, which may be a direct adaptation to frequent human disturbance. In natural forest, mammal activity peaked during daytime. Despite the high mammal diversity in extensively managed coffee forest, it cannot fully replace natural forest as a habitat for large mammals. We suggest that a balanced landscape mosaic of coffee and natural forest may be a valuable combination for both conservation and coffee cultivation.
\end{abstract}

Keywords Afromontane forest, agroforestry, Coffea arabica, conservation, diversity, Ethiopia, large mammals

Supplementary material for this article is available at https://doi.org/10.1017/So030605318000844

Jan E. J. Mertens (Corresponding author), Merlijn Jocoué and Matthias De BEENHOUwER Biodiversity Inventory for Conservation vzw, Walmersumstraat 44, 3380 Glabbeek, Belgium. E-mail bincovzw@gmail.com

Willem-Jan Emsens Ecosystem Management Research Group, Department of Biology, University of Antwerp, Antwerp, Belgium

Lore GeEraert Plant Conservation and Population Biology, Biology Department, Katholieke Universiteit Leuven, Heverlee, Belgium

Received 18 March 2018. Revision requested 16 May 2018.

Accepted 12 June 2018. First published online 6 December 2018.

\section{Introduction}

$\mathrm{O}$ d-growth tropical forest is threatened by increasing pressure from human population growth and land-use change, which generally results in biodiversity loss (Achard et al., 2002; Foley et al., 2005; Gibson et al., 2011). As many people depend directly on forest products for their livelihood, it is expected that human-dominated land-use types will play an increasingly important role in the protection of biodiversity and in the provision of ecosystem services (Gardner et al., 2009; Phalan et al., 2011).

An estimated $46 \%$ of agricultural area worldwide is used as agroforest (Zomer et al., 2009). Agroforestry (an agriculture system incorporating $>10 \%$ tree cover) has been proposed as a way to balance biodiversity conservation with food production and the delivery of ecosystem services (Gardner et al., 2009; Phalan et al., 2011; Fischer et al., 2014; Perfecto et al., 2014). The extent to which tropical agroforest can replace pristine forest in terms of biodiversity is context- and taxa-dependent (e.g. De Beenhouwer et al., 2013).

Coffee (Coffea spp.; family Rubiaceae) is an intensively traded tropical agricultural commodity, with an estimated trade value of USD 24 billion annually (FAO, 2015). It is cultivated in $>60$ countries, and the total area covered by coffee plantations exceeds 11 million ha (Waller et al., 2007). Arabica coffee Coffea arabica originates from Ethiopian montane forests (Anthony et al., 2002) and is, economically, the most important coffee species globally. This species grows naturally under a dense overstorey canopy cover and also requires shade when cultivated. Therefore, Arabica coffee is often cultivated under a canopy of indigenous tree species, which increases the potential of coffee forests to provide ecosystem services and to serve as refuges for wildlife (Philpott et al., 2008; Jha et al., 2014; Perfecto et al., 2014). Global coffee consumption has been increasing at a mean annual rate of $1.3 \%$ since the 1980 s (ICO, 2016) and the pressure on land for coffee production has increased correspondingly. As a result, much of the remaining natural forest is gradually being converted to coffee forest (e.g. Priess et al., 2007; Hylander et al., 2013). The effect of forest conversion for coffee cultivation on biodiversity has been studied for a variety of taxa in Latin America and Asia, but less so in Africa $(<10 \%$ of studies; De Beenhouwer et al., 2013). 
A prime example of coffee forest conversion, and subsequent intensification driven by yield maximization, is in south-west Ethiopia (Schmitt et al., 2010; Aerts et al., 2011). Here, the effect of conversion to agroforestry on forest biodiversity has been evaluated for a variety of taxa: aboveground biodiversity of epiphytes and pollinators (Hylander \& Nemomissa, 2009; Hundera et al., 2013; Samnegård et al., 2014; Berecha et al., 2015) and below-ground biodiversity of arbuscular mycorrhizae (De Beenhouwer et al., 2015a) are generally lower in coffee forest compared to natural forest, whereas bird diversity is similar in both habitats (Buechley et al., 2015; Rodrigues et al., 2018). Little is known about the effect of coffee forest conversion on mammals. Five studies (none in Africa) have examined differences in mammal communities between coffee forest and natural forest. These studies focused on small $(<2 \mathrm{~kg})$ mammals and reported differences in diversity and community composition for non-flying mammals (e.g. Caudill et al., 2015) and bats (Pineda et al., 2005; Williams-Guillén \& Perfecto, 2010). Only one previous study included large mammals in its surveys, and found large mammals to be the first to disappear when more intensive coffee plantations replace extensive forest (Daily et al., 2003). A study of a gradient of landuse intensification suggested that mammal diversity in cocoa and banana agroforests is higher than in monocultures, but lower than in neighbouring areas of natural forest (Harvey et al., 2006).

It is unknown if and how mammal activity patterns are altered following the conversion of natural forest to coffee agroforest. However, some mammals have exhibited behavioural change and have been found to shift their activity in response to habitat fragmentation or conversion (Presley et al., 2009; Norris et al., 2010).

We used camera traps to compare diversity, community composition and activity patterns of large $\left(>_{2} \mathrm{~kg}\right) \mathrm{mam}-$ mals between patches of natural forest and coffee forest in Ethiopia. Our objectives were (1) to record the diversity and distribution of large mammals in a remote area that was not previously the focus of mammal studies, and (2) to assess the effects of conversion from natural forest to coffee agroforest on communities of large mammals.

\section{Study area}

The Belete-Gera National Forest Priority Area, hereafter Belete-Gera forest, is a forest fragment in the Jimma zone, Oromia National Regional State, and is a Key Biodiversity Area within the Eastern Afromontane Biodiversity Hotspot (Fig. 1; Mittermeier et al., 2011). The Belete-Gera forest is an Afromontane evergreen climax forest dominated by Syzygium guineense, Olea welwitschii, Prunus africana and Pouteria adolfi-friedericii (Demissew et al., 2004). The forest covers $>1,500 \mathrm{~km}^{2}$, at 1,400-3,000 m altitude. Mean annual temperature and rainfall at 2,000 $\mathrm{m}$ altitude are $18.4{ }^{\circ} \mathrm{C}$ and $1,780 \mathrm{~mm}$, respectively. Arabica coffee is native to the BeleteGera forest and occurs naturally as an understorey shrub at 1,400-2,200 m altitude. People from various ethnic groups inhabit the region, and they extract coffee, honey, spices, bushmeat, wood and medicines from the forest.

Within the Belete-Gera forest, patches of natural forest are interspersed with patches of intensely cultivated coffee forest. In the natural forest, coffee harvesting occurs on a limited scale, with little anthropogenic disturbance (Supplementary Fig. 1; Schmitt et al., 2010). The coffee forest patches, in contrast, are characterized by higher levels of anthropogenic disturbance, caused by slashing of undergrowth and active planting and replanting of coffee seedlings. Here, the canopy has a more open structure as a result of selective thinning of emergent tree species and saplings (Supplementary Fig. 1; Aerts et al., 2011). Although overall above-ground woody biomass is similar between the forest types, tree diversity is lower in coffee forest (De Beenhouwer et al., 2016). Patches of coffee forest are generally located near the roads between villages and are dominated by tree species such as Milletia ferruginea, Teclea nobilis and S. guineense. Additional differences in forest structure between the two forest types are summarized in Supplementary Table 1.

\section{Methods}

\section{Data collection}

Sixteen wildlife cameras $(1,280 \times 720$ video resolution, motion sensor up to 10 m, 32 IR LED; 10 Bushnell Trophy Cam 2011, model 119436, and six Bushnell Trophy Cam XLT 2011, model 119456; Bushland Corporation, Overland Park, USA) were deployed in the Belete-Gera forest for 6 months during the Ethiopian wet season (August 2014-January 2015). Cameras were placed on transects away from forest trails, rivers and wildlife tracks, and spaced at least $300 \mathrm{~m}$ apart (Fig. 1). Eight cameras were placed in coffee forest and eight in natural forest, simultaneously. At each location we searched for a small forest clearing, to maximize detection distance. We attached the camera to a tree trunk at a height of c. $60 \mathrm{~cm}$ above the forest floor, facing the clearing.

All cameras were relocated to a new transect every 2 months (following Rovero et al., 2014), resulting in a total of 24 deployments each in coffee forest and natural forest (Fig. 1). One camera went missing from coffee forest during the last deployment round, and we were therefore unable to retrieve these data.

Cameras were set to record 30-s videos without delay between consecutive triggers. A re-detection of the same species on a single deployment was treated as a new and independent detection only if a minimum of 5 minutes had passed between recordings. A group of multiple 


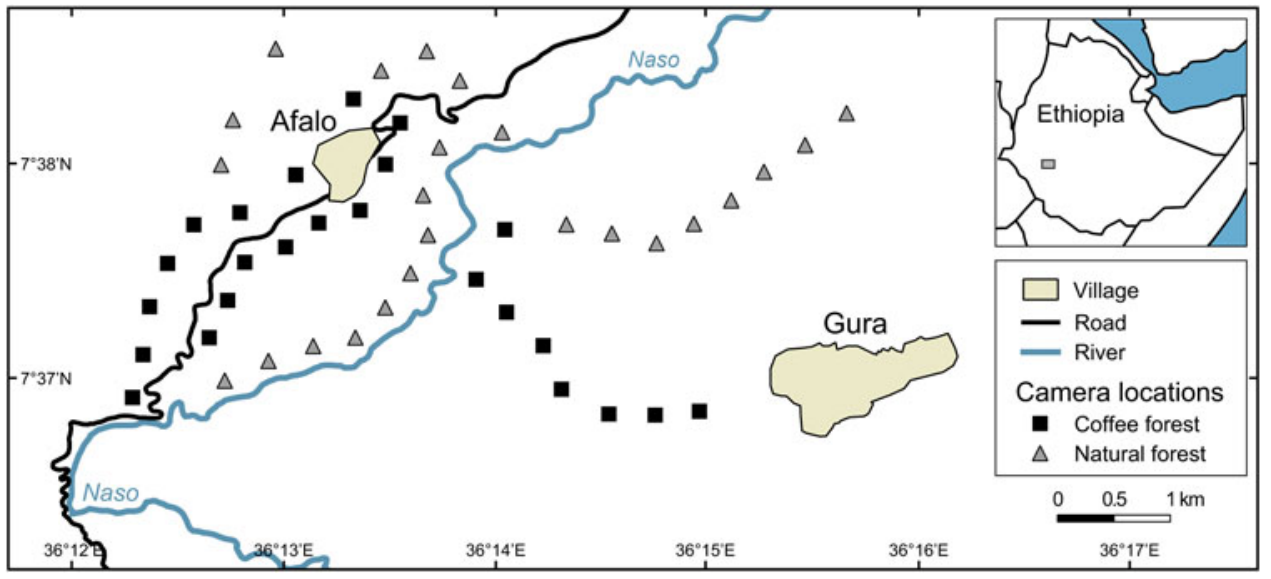

FIG. 1 Locations of camera traps in the Belete-Gera National Forest in south-west Ethiopia. individuals of a species was treated as a single detection for that species, but we recorded group size as metadata. Kingdon (2003) was used for species identification.

\section{Data analysis}

Analyses were in $R$ v.3.2.5 (R Development Core Team, 2017). We ran generalized linear models for count data with Poisson errors or negative binomial errors (in case of overdispersion) to test for differences in total species counts (species richness) and total number of mammal detections between deployments in coffee forest and natural forest. Because the number of detections usually increases with camera deployment duration, the logarithm of deployment duration (in hours) was included in each model as an offset. We also compared mammal diversity (Shannon diversity index) between both forest types using a WilcoxonMann-Whitney U test, in which each deployment was treated as an independent observation.

To test for the effect of forest type on mammal community composition, we performed non-metric multidimensional scaling (NMDS) on the sample $\mathrm{x}$ species matrix, using Bray-Curtis distances ( $R$ package vegan, Oksanen et al., 2013). Subsequently, differences in community composition between forest types were tested for significance based on a permutation test with 999 iterations, using the function envfit (vegan package).

Additionally, we ran an indicator species analysis to determine indicator species for each forest type, using PC-ORD 6.o (McCune \& Mefford, 2011). In this analysis an indicator value is based on fidelity and relative abundance of a species in relation to forest type. By definition, an indicator value of 100 (perfect indicator species) implies that the presence of a given species identifies a forest type without error. The obtained indicator values were tested for significance using a Monte Carlo randomization test with 1,00o permutations.

We created activity overlap plots for all mammal species for coffee forest and natural forest separately by fitting kernel density functions of activity times in the $R$ package overlap (Meredith \& Ridout, 2014). A minimum of two unique observations per forest type was required to fit a kernel density: species with fewer observations were excluded from the analyses.

\section{Results}

Species richness and diversity

A total of 19 large mammal species were recorded in the Belete-Gera forest (Table 1), all of which are categorized as Least Concern on the IUCN Red List except the leopard Panthera pardus (Stein et al., 2016) and the blue monkey Cercopithecus mitis ssp. boutourlinii (Butynski \& Gippoliti, 2008), which are categorized as Vulnerable. Across the study period a total of 19,059 camera-trap hours were accumulated in coffee forest ( 23 deployments, mean $=829$ hours per deployment) and 22,272 camera-trap hours in natural forest ( 24 deployments, mean $=928$ hours per deployment). The number of mammal species recorded per deployment was o-8, with medians of 4 and 5 species per deployment in coffee forest and natural forest, respectively. In total, 15 mammal species were encountered in coffee forest and 16 in natural forest (Table 1). Number of species detected per camera trap did not differ between the two forest types (generalized linear model negative binomial $\beta=-0.17 \pm$ SE $0.16, P=0.27$ ). Median Shannon diversity indices were 3.83 and 3.42 in coffee forest and natural forest, respectively, but the difference was non-significant (Wilcoxon-Mann-Whitney $\mathrm{W}=303.5, \mathrm{P}=0.561$ ).

\section{Community composition}

Overall community composition of large mammals varied across NMDS axis 1 (explaining $30.1 \%$ of the variation) and axis 2 (explaining $36.9 \%$ of the variation; Fig. 2). 
TABLE 1 Species of large ( $>2 \mathrm{~kg}$ ) mammals detected by camera traps during a 6-month survey in the Belete-Gera National Forest, Ethiopia (Fig. 1).

\begin{tabular}{|c|c|c|c|c|c|}
\hline \multirow[b]{2}{*}{ Species } & \multicolumn{2}{|l|}{ Deployments $^{1}$} & \multicolumn{2}{|l|}{ Detections $^{2}$} & \multirow[b]{2}{*}{ Group size $^{3}$ (range) } \\
\hline & Natural forest & Coffee forest & Natural forest & Coffee forest & \\
\hline People & 9 & 14 & 49 & 331 & \\
\hline Olive baboon Papio anubis & 19 & 14 & 46 & 42 & $4.11(1-18)$ \\
\hline Bush duiker Sylvicapra grimmia & 11 & 15 & 43 & 69 & $1.04(1-2)$ \\
\hline Bushbuck Tragelaphus scriptus & 15 & 19 & 38 & 61 & $1.13(1-2)$ \\
\hline Blotched genet Genetta maculata & 13 & 8 & 32 & 14 & 1 \\
\hline Giant forest hog Hylochoerus meinertzhageni & 10 & 14 & 30 & 43 & $2.27(1-9)$ \\
\hline Cape buffalo Syncerus caffer & 7 & 3 & 24 & 6 & $1.80(1-5)$ \\
\hline African civet Civettictis civetta & 6 & 2 & 16 & 4 & 1 \\
\hline Bushpig Potamochoerus larvatus & 9 & 13 & 13 & 30 & $2.30(1-7)$ \\
\hline Leopard Panthera pardus & 6 & 1 & 8 & 2 & $1.1(1-2)$ \\
\hline Marsh mongoose Atilax paludinosus & 2 & 0 & 2 & 0 & 1 \\
\hline Crested porcupine Hystrix cristata & 1 & 7 & 1 & 12 & $1.23(1-2)$ \\
\hline Side-striped jackal Canis adustus & 1 & 2 & 1 & 4 & 1 \\
\hline Blue monkey Cercopithecus mitis ssp. boutourlinii & 1 & 0 & 1 & 0 & 1 \\
\hline De Brazza's monkey Cercopithecus neglectus & 1 & 0 & 1 & 0 & 1 \\
\hline Warthog Phacochoerus africanus & 1 & 0 & 1 & 0 & 4 \\
\hline Ethiopian hare Lepus fagani & 0 & 4 & 0 & 7 & 1 \\
\hline Spotted hyena Crocuta crocuta & 0 & 3 & 0 & 3 & 1 \\
\hline Honey badger Mellivora capensis & 0 & 1 & 0 & 1 & 1 \\
\hline
\end{tabular}

${ }^{1}$ Total number of camera deployments in which a species was observed.

${ }^{2}$ Total number of independent species detections per forest type.

${ }^{3}$ Mean number of individuals per species simultaneously captured on camera.

Community composition differed significantly between the two forest types $\left(r^{2}=0.24, \mathrm{P}=0.003\right)$.

Of the 19 species recorded, six were relatively abundant in both forest types: bushbuck Tragelaphus scriptus ( $72 \%$ of deployments), olive baboon Papio anubis (70\% of deployments), bush duiker Sylvicapra grimmia (55\%), giant forest hog Hylochoerus meinertzhageni (51\%), bush pig Potamochoerus larvatus (47\%) and blotched genet Genetta maculata (45\%; Table 1). Five other species were also encountered in both forest types, although less frequently: Cape buffalo Syncerus caffer, African civet Civettictis civetta, crested porcupine Hystrix cristata, leopard and side-striped jackal Canis adustus. Three species (spotted hyena Crocuta crocuta, honey badger Mellivora capensis and Ethiopian hare Lepus fagani) were encountered exclusively (although uncommonly) in coffee forest, whereas four species were restricted to natural forest (blue monkey, De Brazza's monkey Cercopithecus neglectus, marsh mongoose Atilax paludinosus and warthog Phacochoerus africanus), but were uncommon in the recordings. The crested porcupine and Ethiopian hare were significant indicator species of coffee forest, and the leopard and African civet had a preference for natural forest, but not significantly so (Table 2).

\section{Activity patterns}

We accumulated a total of 555 independent detections of mammals in both forest habitats combined: 298 in coffee forest and 257 in natural forest (Table 1). The number of independent detections per camera deployment was o-31, and was slightly higher in coffee forest (median $=12$ detections) than in natural forest (median $=10$ detections; generalized linear model negative binomial $\beta=-0.38 \pm$ SE 0.19, $\mathrm{P}=0.049$ ).

Daily activity patterns also varied between forest types. For all species combined, we observed two main peaks in mammal activity: overall mammal activity in natural forest peaked in the late morning and again in the late afternoon, whereas overall mammal activity in coffee forest peaked a few hours before sunrise and again around dusk (Fig. 3a). We also observed intraspecific differences in daily activity between the forest types. Bushbuck activity in natural forest was primarily diurnal and peaked in the morning and afternoon. In coffee forest, however, the species shifted to crepuscular and nocturnal activity (Fig. 3b). Another clear activity shift was observed for the giant forest hog; in natural forest, hog activity was primarily diurnal, with a unimodal peak in the late afternoon just before dusk (Fig. 3d), whereas in coffee forest its activity was primarily nocturnal and bimodal, with peaks well after sunset and well before sunrise. A similar, but less strong shift in daily bimodal activity was apparent for the bush duiker; although primarily diurnal, duikers were active earlier (just after sunrise) and later (just before sunset) in coffee forest than in natural forest (Fig. 3c). Leopard activity was also primarily diurnal and crepuscular in natural forest but nocturnal in coffee forest; 


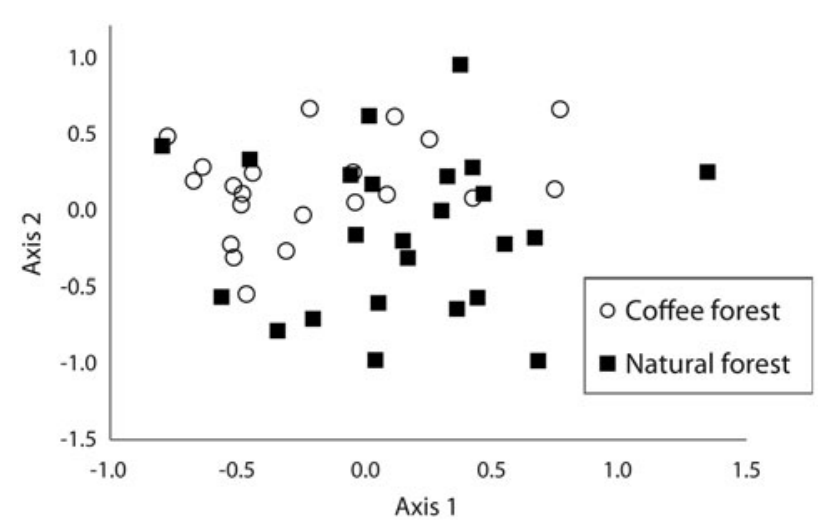

FIG. 2 Non-metric multidimensional scaling ordination plot of the community composition of large $(>2 \mathrm{~kg})$ mammals in natural and coffee forest of the Belete-Gera National Forest, Ethiopia (Fig. 1). The closer samples (camera-trap points) occur within the plot, the greater the similarity in their community composition. Communities differed significantly between coffee and natural forest.

however, the number of independent observations was low ( 2 and 8 in coffee and natural forest, respectively). The other species that occurred in both forest types were primarily nocturnal (i.e. bushpig, Fig. 3e; buffalo, Fig. 3f; civet, Fig. $3 \mathrm{~h}$; and genet, Fig. $3 \mathrm{i}$ ). As expected, the olive baboon was the only species with a distinct peak in daytime activity in both forest types (Fig. $3 \mathrm{~g}$ ). All remaining species were either exclusive to one forest type or we had too few observations to estimate activity curves (Supplementary Fig. 2).

\section{Discussion}

\section{Species richness and diversity}

Species richness and diversity of large mammals were similar in coffee forest and natural forest. Such similarity has not been reported from earlier research comparing other types of agroforestry with natural forest. Studies on banana (Harvey et al., 2006) and cocoa (Cassano et al., 2012) agroforestry found significantly lower mammal diversity compared to natural forest. Coffee forest in the Belete-Gera forest, however, can be considered extensively managed agroforest. The growth of coffee plants is promoted through selective cutting of understorey shrubs and additional planting of wild coffee seeds. In this process a species-rich and diverse tree canopy is maintained (e.g. Aerts et al., 2011; De Beenhouwer et al., 2016). The remaining forest structure sustains a high diversity of birds (Rodrigues et al., 2018) and epiphytes (De Beenhouwer et al., 2015b). Through this extensively managed approach, and in accordance with previous research, Ethiopian coffee forest may provide one of the most biodiversity-friendly coffee crops in the world (Buechley et al., 2015).
TABle 2 Monte Carlo test (see text for details) of significance of indicator species for natural coffee forest in the south-western Ethiopian forest landscape.

\begin{tabular}{llll}
\hline Species & Preference & Indicator value & $\mathrm{P}$ \\
\hline Leopard & Natural forest & 22.4 & 0.081 \\
African civet & Natural forest & 22.7 & 0.063 \\
Spotted hyena & Coffee forest & 14.3 & 0.094 \\
Crested porcupine & Coffee forest & 31.5 & 0.008 \\
Ethiopian hare & Coffee forest & 19.0 & 0.040 \\
\hline
\end{tabular}

\section{Community composition}

Composition of large mammal communities differed between coffee forest and natural forest. These results follow those of similar studies on mammal communities in Costa Rica and India, where coffee forest also hosts distinct mammal communities in comparison with natural forest (Daily et al., 2003; Caudill et al., 2015). This shift in mammal communities has also been observed in other agroforestry systems, including cocoa and banana (Harvey et al., 2006; Cassano et al., 2012).

In our study the leopard and African civet showed a tendency towards natural forest, whereas the crested porcupine and Ethiopian hare were true indicator species of coffee forest (Table 2). The latter two species are not commonly associated with forest (Kingdon, 2003), so their presence in coffee forest may be related to frequent anthropogenic disturbances (e.g. understorey cutting) and increased forest accessibility, which generally facilitates the distribution of hemerophile species (Brodie et al., 2015). In addition, a concomitant decrease in canopy cover (Supplementary Table 1) and shifts in vegetation composition affect habitat quality and resource availability (Bawa \& Seidler, 1998), which may also trigger shifts in mammal community composition (Daily et al., 2003; Caudill et al., 2015).

\section{Altered activity patterns}

Overall mammal activity, which we defined as the total number of independent mammal detections, was higher in coffee forest than in natural forest. Forest accessibility possibly plays a role here; the denser natural forest restricts movement of larger mammals. Seasonally, the understorey in extensively managed coffee forest is removed and is easier to pass through. Also, human presence was recorded on $49 \%$ of the deployments, although with higher frequency and abundance in coffee forest, where 14 camera traps detected people on 331 occasions, compared to nine camera traps and 49 occasions in natural forest. Mammal activity in coffee forest was predominantly crepuscular and nocturnal, whereas activity in natural forest peaked during daytime. Shifts in activity were observed between species (e.g. more 

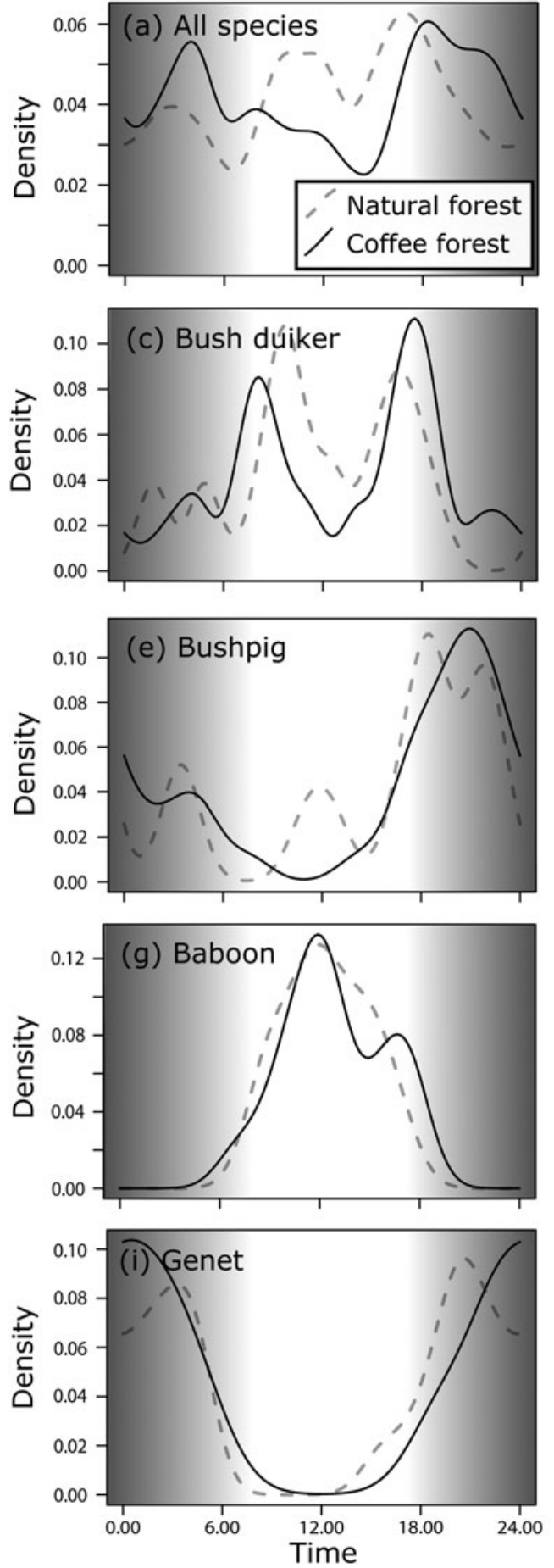
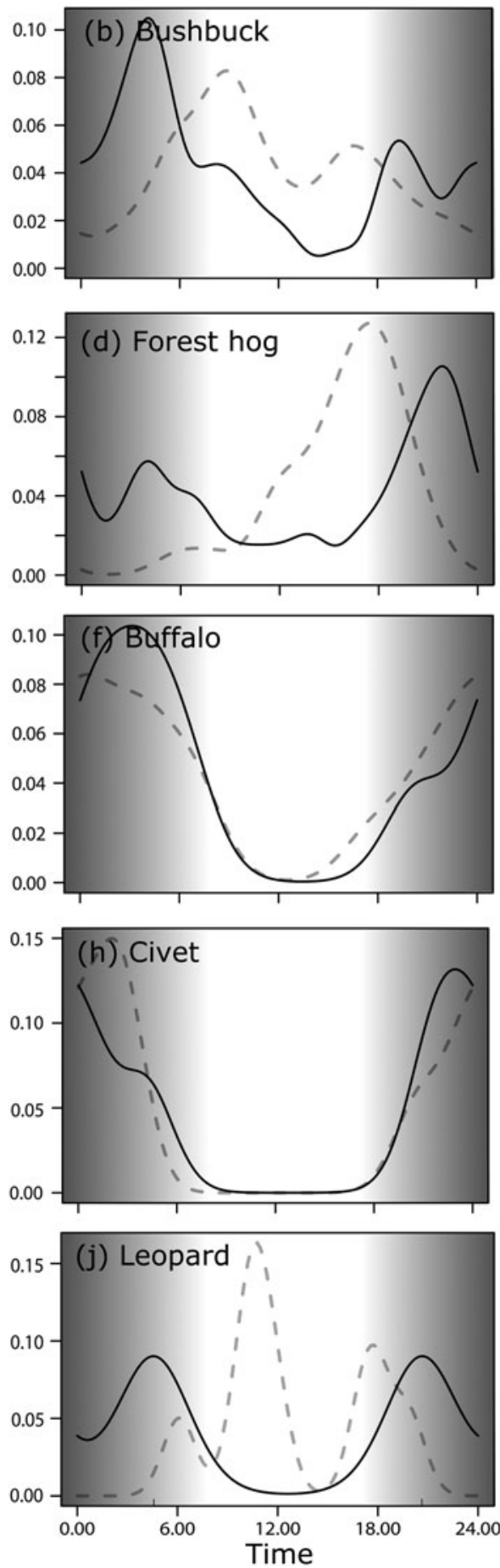

FIG. 3 Daily activity patterns of large $(>2 \mathrm{~kg})$ mammals in natural and coffee forest of the Belete-Gera National Forest, Ethiopia (Fig. 1), based on camera-trap data. Activity times were fitted with kernel density functions (a relative distribution of total activity). Shading indicates night-time. Note the differing scales of the $y$-axes. nocturnal species in coffee forest), and within species (e.g. bushbuck and forest hog). Such activity shifts in coffee forest may be a direct consequence of higher levels of anthropogenic disturbance. Also, greater accessibility to the forest can facilitate bushmeat hunting (Poulsen et al., 2009), which is a significant threat for mammal communities throughout Africa (Craigie et al., 2010), although a relatively low threat in our study area, based on personal observations and interviews.

\section{Coffee forest at the landscape level}

As shown for other crops, we hypothesize that the complete loss or absence of natural forest in combination with increased anthropogenic disturbance could result in the local extinction of top predators, such as leopards, which would then trigger a myriad of cascading effects on mammal communities and other forest components (Colman et al., 2015). We found that extensively managed coffee forest 
harboured a diverse community of large mammals. It is important to recognize, however, that coffee forest cannot fully replace natural forest as a habitat for large mammals, but that a balanced landscape mosaic of coffee and natural forest may be a valuable combination for both conservation and coffee cultivation. Coffee forest could also fulfil a role as a high-diversity buffer for natural forest core zones (Asare et al., 2014), while generating income for local communities (Hylander et al., 2013; De Beenhouwer et al., 2016). Economic sustainability of small-scale coffee production can be enhanced by certification for wild or biodiversityfriendly coffee beans (Perfecto et al., 2005; Wiersum et al., 2008), and local farmers can be compensated financially for increased carbon storage in agroforest (De Beenhouwer et al., 2016).

Acknowledgements We thank the Rufford Foundation (Grant 14969-1) and Idea Wild for financial support; VLIR-UOS and Jimma University for logistical support; Biodiversity Inventory for Conservation members for help with the experimental setup; Sabit, Amino and Aba Sharo for help in the field; and the people of Gera woreda and Afalo kebele for research permissions.

Author contributions Fieldwork planning and execution: JEJM, LG, MDB, MJ; data analysis: MDB, WJE; writing: JEJM, MDB, MJ, WJE.

\section{Conflicts of interest None.}

Ethical standards We used non-invasive, unbaited, motiontriggered camera traps. Data collection did not involve direct contact or interaction with animals. Fieldwork was with permission of the Oromia Forest and Wildlife Enterprise (Jimma zone) and the Gera woreda (Jimma zone).

\section{References}

Achard, F., Eva, H.D., Stibig, H.-J., Mayaux, P., Gallego, J., Richards, T. \& Malingreau, J.-P. (2002) Determination of deforestation rates of the world's humid tropical forests. Science, 297, 999-1002.

Aerts, R., Hundera, K., Berecha, G., Gijbels, P., Baeten, M., Van Mechelen, M. et al. (2011) Semi-forest coffee cultivation and the conservation of Ethiopian Afromontane rainforest fragments. Forest Ecology and Management, 261, 1034-1041.

Anthony, F., Combes, M., Astorga, C., Bertrand, B., Graziosi, G. \& Lashermes, P. (2002) The origin of cultivated Coffea arabica L. varieties revealed by AFLP and SSR markers. Theoretical and Applied Genetics, 104, 894-900.

Asare, R., Afari-Sefa, V., Osei-Owusu, Y. \& Pabi, O. (2014) Cocoa agroforestry for increasing forest connectivity in a fragmented landscape in Ghana. Agroforestry Systems, 88, 1143-1156.

BAwA, K.S. \& SEIdler, R. (1998) Natural forest management and conservation of biodiversity in tropical forests. Conservation Biology, 12, 46-55.

Berecha, G., Aerts, R., Muys, B. \& Honnay, O. (2015) Fragmentation and management of Ethiopian moist evergreen forest drive compositional shifts of insect communities visiting wild Arabica coffee flowers. Environmental Management, 55, 373-382.
Brodie, J.F., Giordano, A.J. \& Ambu, L. (2015) Differential responses of large mammals to logging and edge effects. Mammalian Biology, 80, 7-13.

Buechley, E.R., Şekercioğlu, Ç.H., Atickem, A., Gebremichael, G., Ndungu, J.K., Mahamued, B.A. et al. (2015) Importance of Ethiopian shade coffee farms for forest bird conservation. Biological Conservation, 188, 50-60.

Butynski, T.M. \& Gippoliti, S. (2008) Cercopithecus mitis ssp. boutourlinii. The IUCN Red List of Threatened Species 2008: e.T136901A4349249. Http://dx.doi.org/10.2305/IUCN.UK.2008. RLTS.T136901A4349249.en [accessed 11 October 2018].

Cassano, C.R., Barlow, J. \& Pardini, R. (2012) Large mammals in an agroforestry mosaic in the Brazilian Atlantic Forest. Biotropica, $44,818-825$.

Caudill, S.A., DeClerck, F.J.A. \& Husband, T.P. (2015) Connecting sustainable agriculture and wildlife conservation: does shade coffee provide habitat for mammals? Agriculture, Ecosystems \& Environment, 199, 85-93.

Colman, N.J., Crowther, M.S. \& Letnic, M. (2015) Macroecological patterns in mammal abundances provide evidence that an apex predator shapes forest ecosystems by suppressing herbivore and mesopredator abundance. Journal of Biogeography, 42, 1975-1985.

Craigie, I.D., Baillie, J.E.M., Balmford, A., Carbone, C., Collen, B., Green, R.E. \& Hutton, J.M. (2010) Large mammal population declines in Africa's protected areas. Biological Conservation, 143, 2221-2228.

Daily, G.C., Ceballos, G., Pacheco, J., Suzán, G. \& SÁnCheZ-AzofeIfA, A. (2003) Countryside biogeography of Neotropical mammals: conservation opportunities in agricultural landscapes of Costa Rica. Conservation Biology, 17, 1814-1826.

De Beenhouwer, M., Aerts, R. \& Honnay, O. (2013) A global meta-analysis of the biodiversity and ecosystem service benefits of coffee and cacao agroforestry. Agriculture, Ecosystems and Environment, 175, 1-7.

De Beenhouwer, M., Muleta, D., Peeters, B., Van Geel, M., Lievens, B. \& Honnay, O. (2015a) DNA pyrosequencing evidence for large diversity differences between natural and managed coffee mycorrhizal fungal communities. Agronomy for Sustainable Development, 35, 241-249.

De Beenhoumer, M., Aerts, R., Hundera, K., Van Overtveld, K. \& Honnay, O. (2015b) Management intensification in Ethiopian coffee forests is associated with crown habitat contraction and loss of specialized epiphytic orchid species. Basic and Applied Ecology, $16,592-600$.

De Beenhoumer, M., Geeraert, L., Mertens, J., Van Geel, M., Aerts, R., Vanderhaegen, K. \& Honnay, O. (2016) Biodiversity and carbon storage co-benefits of coffee agroforestry across a gradient of increasing management intensity in the SW Ethiopian highlands. Agriculture, Ecosystems \& Environment, 222, 193-199.

Demissew, S., Cribi, P. \& Rasmussen, F.N. (2004) Field Guide to Ethiopian Orchids. Royal Botanic Gardens, Kew, UK.

Fischer, J., Abson, D.J., Butsic, V., Chappell, M.J., Ekroos, J., HANSPACH, J. et al. (2014) Land sparing versus land sharing: moving forward. Conservation Letters, 7, 149-157.

Foley, J.A., DeFries, R., Asner, G.P., Barford, C., Bonan, G., Carpenter, S.R. et al. (2005) Global consequences of land use. Science, 309, 570-574.

FaO (Food and Agriculture Organization of the United Nations) (2015) FAO Statistical Pocketbook: Coffee 2015. FAO, Rome, Italy.

Gardner, T.A., Barlow, J., Chazdon, R., Ewers, R.M., Harvey, C. A., Peres, C.A. \& Sodhi, N.S. (2009) Prospects for tropical forest biodiversity in a human-modified world. Ecology Letters, 12, 561-582. 
Gibson, L., Lee, T.M., Koh, L.P., Brook, B.W., Gardner, T.A., BARLOW, J. et al. (2011) Primary forests are irreplaceable for sustaining tropical biodiversity. Nature, $478,378-381$.

Harvey, C.A., Gonzalez, J. \& Somarriba, E. (2006) Dung beetle and terrestrial mammal diversity in forests, indigenous agroforestry systems and plantain monocultures in Talamanca, Costa Rica. Biodiversity and Conservation, 15, 555-585.

Hundera, K., Aerts, R., Fontaine, A., Van Mechelen, M., Gijbels, P., Honnay, O. \& Muys, B. (2013) Effects of coffee management intensity on composition, structure, and regeneration status of Ethiopian moist evergreen Afromontane forests. Environmental Management, 51, 801-809.

Hylander, K. \& Nemomissa, S. (2009) Complementary roles of home gardens and exotic tree plantations as alternative habitats for plants of the Ethiopian montane rainforest. Conservation Biology, 23, 400-409.

Hylander, K., Nemomissa, S., Delrue, J. \& Enkosa, W. (2013) Effects of coffee management on deforestation rates and forest integrity. Conservation Biology, 27, 1031-1040.

iCO (International Coffee Organization) (2016) The current state of the global coffee trade. Version 14 October 2016. Http://www. ico.org/monthly_coffee_trade_stats.asp [accessed 29 November 2017].

Jha, S., Bacon, C.M., Philpott, S.M., Méndez, V.E., Läderach, P. \& RICE, R.A. (2014) Shade coffee: update on a disappearing refuge for biodiversity. BioScience, 64, 416-428.

Kingdon, J. (2003) The Kingdon Field Guide to African Mammals. A\&C Black Publishers, London, UK.

McCune, B. \& Mefford, M.J. (2011) PC-ORD: multivariate analysis of ecological data. MjM Software, Gleneden Beach, Oregon, USA.

Meredith, M. \& Ridout, M. (2014) Overlap: Estimates of Coefficient of Overlapping for Animal Activity Patterns. $R$ package version o.2.4

Mittermeier, R.A., Turner, W.R., Larsen, F.W., Brooks, T.M. \& GAscon, C. (2011) Global biodiversity conservation: the critical role of hotspots. In Biodiversity Hotspots (eds F.E. Zachos \& J.C. Habel) pp. 3-22. Springer, Berlin, Heidelberg, Germany.

Norris, D., Michalski, F. \& Peres, C.A. (2010) Habitat patch size modulates terrestrial mammal activity patterns in Amazonian forest fragments. Journal of Mammalogy, 91, 551-560.

Oksanen, J., Blanchet, G., Kindt, R., Legendre, P., Minchin, P. R., O'HA RA, R.B., et al. (2013) Vegan: Community Ecology Package. $R$ package version 2.0-10.

Perfecto, I., Vandermeer, J., Mas, A. \& Pinto, L.S. (2005) Biodiversity, yield, and shade coffee certification. Ecological Economics, 54, 435-446.

Perfecto, I., Vandermeer, J. \& Philpott, S.M. (2014) Complex ecological interactions in the coffee agroecosystem. Annual Review of Ecology, Evolution, and Systematics, 45, 137-158.

Phalan, B., Onial, M., Balmford, A. \& Green, R.E. (2011) Reconciling food production and biodiversity conservation: land sharing and land sparing compared. Science, 333, 1289-1291.

Philpott, S.M., Arendt, W.J., Armbrecht, I., Bichier, P., Diestch, T.V., Gordon, C. et al. (2008) Biodiversity loss in Latin American coffee landscapes: review of the evidence on ants, birds, and trees. Conservation Biology, 22, 1093-1105.
Pineda, E., Moreno, C., Escobar, F. \& Halffter, G. (2005) Frog, bat, and dung beetle diversity in the cloud forest and coffee agroecosystems of Veracruz, Mexico. Conservation Biology, 19, 400410.

Poulsen, J.R., Clark, C.J., Mavah, G. \& Elkan, P.W. (2009) Bushmeat supply and consumption in a tropical logging concession in northern Congo. Conservation Biology, 23, 1597-1608.

Presley, S.J., Willig, M.R., Castro-Arellano, I. \& Weaver, S.C. (2009) Effects of habitat conversion on temporal activity patterns of phyllostomid bats in lowland Amazonian rain forest. Journal of Mammalogy, 90, 210-221.

Priess, J.A., Mimler, M., Klein, A.M., Schwarze, S., Tscharntke, T. \& Steffan-Dewenter, I. (2007) Linking deforestation scenarios to pollination services and economic returns in coffee agroforestry systems. Ecological Applications, 17, 407-417.

R Development Core Team (2017) R: A Language and Environment for Statistical Computing. R Foundation for Statistical Computing, Vienna, Austria. Https://www.r-project.org/ [accessed 16 November 2018].

Rodrigues, P., Shumi, G., Dorresteijn, I., Schultner, J., Hanspach, J., Hylander, K. et al. (2018) Coffee management and the conservation of forest bird diversity in southwestern Ethiopia. Biological Conservation, 217, 131-139.

Rovero, F., Martin, E., Rosa, M., Ahumada, J.A. \& Spitale, D. (2014) Estimating species richness and modelling habitat preferences of tropical forest mammals from camera trap data. PLOS ONE, 9, e103300.

Samnegård, U., Hambäck, P.A., Nemomissa, S. \& Hylander, K. (2014) Dominance of the semi-wild honeybee as coffee pollinator across a gradient of shade-tree structure in Ethiopia. Journal of Tropical Ecology, 30, 401-408.

Schmitt, C.B., Senbeta, F., Denich, M., Preisinger, H. \& Boehmer, H.J. (2010) Wild coffee management and plant diversity in the montane rainforest of southwestern Ethiopia. African Journal of Ecology, 48, 78-86.

Stein, A.B., Athreya, V., Gerngross, P., Balme, G., Henschel, P., Karanth, U.A. et al. (2016) Panthera pardus (errata version published in 2016). The IUCN Red List of Threatened Species 2016: e.T15954A102421779. Http://dx.doi.org/10.2305/ IUCN.UK.2016-1.RLTS.T15954A50659089.en [accessed 11 October 2018].

Waller, J.M., Bigger, M. \& Hillocks, R.J. (2007) Coffee Pests, Diseases and their Management. CABI, Wallingford, UK.

Wiersum, K.F., Gole, T.W., Gatzweiler, F., Volkmann, J., Bognetteau, E. \& Wirtu, O. (2008) Certification of wild coffee in Ethiopia: experiences and challenges. Forests, Trees and Livelihoods, 18, 9-21.

Williams-Guillén, K. \& Perfecto, I. (2010) Effects of agricultural intensification on the assemblage of leaf-nosed bats (Phyllostomidae) in a coffee landscape in Chiapas, Mexico. Biotropica, 42, 605-613.

Zomer, R.A., Trabucco, A., Coe, R. \& Place, F. (2009) Trees on farm: analysis of global extent and geographical patterns of agroforestry. ICRAF Working Paper no. 89. World Agroforestry Centre, Nairobi, Kenya. 